\title{
Tropical temperature variability and Kelvin-wave activity in the UTLS from GPS RO measurements
}

\author{
Barbara Scherllin-Pirscher ${ }^{1,2}$, William J. Randel ${ }^{3}$, and Joowan Kim ${ }^{3,4}$ \\ ${ }^{1}$ Wegener Center for Climate and Global Change (WEGC) and Institute for Geophysics, Astrophysics, and \\ Meteorology/Institute of Physics (IGAM/IP), University of Graz, Graz, Austria \\ ${ }^{2}$ Zentralanstalt für Meteorologie und Geodynamik (ZAMG), Vienna, Austria \\ ${ }^{3}$ National Center for Atmospheric Research (NCAR), Boulder, Colorado, USA \\ ${ }^{4}$ Department of Atmospheric Sciences, Kongju National University, Gongju, Korea
}

Correspondence to: Barbara Scherllin-Pirscher (barbara.scherllin-pirscher@zamg.ac.at)

Received: 3 July 2016 - Published in Atmos. Chem. Phys. Discuss.: 21 July 2016

Revised: 27 October 2016 - Accepted: 15 December 2016 - Published: 18 January 2017

\begin{abstract}
Tropical temperature variability over $10-30 \mathrm{~km}$ and associated Kelvin-wave activity are investigated using GPS radio occultation (RO) data from January 2002 to December 2014. RO data are a powerful tool for quantifying tropical temperature oscillations with short vertical wavelengths due to their high vertical resolution and high accuracy and precision. Gridded temperatures from GPS RO show the strongest variability in the tropical tropopause region (on average $3 \mathrm{~K}^{2}$ ). Large-scale zonal variability is dominated by transient sub-seasonal waves $\left(2 \mathrm{~K}^{2}\right)$, and about half of subseasonal variance is explained by eastward-traveling Kelvin waves with periods of 4 to 30 days $\left(1 \mathrm{~K}^{2}\right)$. Quasi-stationary waves associated with the annual cycle and interannual variability contribute about a third $\left(1 \mathrm{~K}^{2}\right)$ to total resolved zonal variance. Sub-seasonal waves, including Kelvin waves, are highly transient in time. Above $20 \mathrm{~km}$, Kelvin waves are strongly modulated by the quasi-biennial oscillation (QBO) in stratospheric zonal winds, with enhanced wave activity during the westerly shear phase of the QBO. In the tropical tropopause region, however, peaks of Kelvin-wave activity are irregularly distributed in time. Several peaks coincide with maxima of zonal variance in tropospheric deep convection, but other episodes are not evidently related. Further investigations of convective forcing and atmospheric background conditions are needed to better understand variability near the tropopause.
\end{abstract}

\section{Introduction}

Atmospheric temperature variability in the tropics is coupled with dynamical and physical processes, which have a crucial impact on the Earth's climate. Variability in the tropical tropopause region is of special interest because it has an important role in troposphere-stratosphere coupling and exchange (Holton et al., 1995; Fueglistaler et al., 2009) and associated global radiation budget. Thus, detailed knowledge of dynamical processes in the tropical upper troposphere and stratosphere is essential for better understanding climate variability and change. It has been found, for example, that decadal variations in global surface climate may be significantly influenced by changes in stratospheric water vapor (Solomon et al., 2010), which is controlled by temperatures near the tropical tropopause (Mote et al., 1996). Furthermore, vertically propagating equatorial waves, which originate from the troposphere and propagate into the upper atmosphere, are main drivers of global-scale zonal wind variation, which is called the quasi-biennial oscillation (QBO). The QBO manifests itself as alternating easterly and westerly zonal winds in the tropical stratosphere with a period of approximately 28 months. It has large impacts on the entire global atmosphere (Baldwin et al., 2001).

Equatorial atmospheric waves, including eastwardpropagating Kelvin waves, are generated by heating associated with convection (e.g., Garcia and Salby, 1987; Wheeler and Kiladis, 1999).

Kelvin waves in the troposphere have been identified with convection (Wheeler and Kiladis, 1999; Wheeler et al., 
2000). These features have zonal wave numbers $\sim 3-7$ and periods $\sim 4-10$ days and move coherently with convection. Above the troposphere, Kelvin waves are observed with planetary scales (zonal wave numbers 1 to 5), periods from a few days to a few tens of days, and vertical wavelengths of a couple of kilometers to more than $10 \mathrm{~km}$ (Andrews et al., 1987; Tsuda et al., 1994; Randel and Wu, 2005; Alexander and Ortland, 2010). They are equatorially trapped and perturb the zonal wind and temperature fields. Atmospheric Kelvin waves were theorized by Matsuno (1966) and Holton and Lindzen (1968) and first observed by Wallace and Kousky (1968). Kelvin waves can propagate vertically in regions of background easterly winds, while they become trapped below regions of westerly winds, and they exhibit strong interactions with the stratospheric QBO (e.g., Sato and Dunkerton, 1997).

Kelvin waves dominate sub-seasonal variability in the tropical tropopause region (Tindall et al., 2006; Kim and Son, 2012). They modulate the height and temperature of the tropical tropopause (Tsuda et al., 1994; Shimizu and Tsuda, 1997) and were found to be important for cirrus formation (Boehm and Verlinde, 2000; Immler et al., 2008; Suzuki et al., 2013) and dehydration of air entering the lower stratosphere (Fujiwara et al., 2001). Furthermore, they play an important role in stratosphere-troposphere exchange of ozone (Fujiwara et al., 1998).

Kelvin waves have been identified using radiosonde wind and temperature measurements (e.g., Wallace and Kousky, 1968; Tsuda et al., 1994; Holton et al., 2001). Due to the limited spatial coverage of the radiosonde network, observations were confined to a few specific locations. Later, satellite temperature measurements provided a more global view on atmospheric dynamics. Equatorial atmospheric waves have been investigated using satellite data from Nimbus-7 LIMS (Limb Infrared Monitor of the Stratosphere; Salby et al., 1984), the Microwave Limb Sounder (MLS; Mote et al., 2002), SABER (Sounding of the Atmosphere using Broadband Emission Radiometry; Ern et al., 2008; Ern and Preusse, 2009), and High Resolution Dynamics Limb Sounder (HIRDLS; Alexander and Ortland, 2010). Furthermore, several studies on atmospheric Kelvin waves are based on analysis or reanalysis data from numerical weather prediction (NWP) centers (Tindall et al., 2006; Suzuki and Shiotani, 2008; Suzuki et al., 2010; Fujiwara et al., 2012; Flannaghan and Fueglistaler, 2013).

Since 2001, highly accurate temperature soundings have continuously been available from Global Positioning System (GPS) radio occultation (RO) measurements. Due to their characteristics of high vertical resolution, accuracy, and global coverage (see Sect. 2.1 for more details) these data have been extensively used to analyze temperature variability and Kelvin-wave activity in the upper troposphere and lower stratosphere (UTLS) region (Tsai et al., 2004; Randel and Wu, 2005; Ratnam et al., 2006; Gettelman and Birner, 2007; Alexander et al., 2008; Steiner et al., 2011; Kim and Son,
2012; Scherllin-Pirscher et al., 2012; Das and Pan, 2013; Flannaghan and Fueglistaler, 2013; Randel and Wu, 2015).

In this study we utilize the entire RO record from 2002 to 2014 to investigate long-term behavior of zonal temperature variability and Kelvin-wave activity over altitudes 10$30 \mathrm{~km}$. We use GPS RO data from Challenging Mini-Satellite Payload (CHAMP; Wickert et al., 2001), Gravity Recovery and Climate Experiment (GRACE; Wickert et al., 2005), Satélite de Aplicaciones Científicas (SAC-C; Hajj et al., 2004), and Formosa Satellite mission-3/Constellation Observing System for Meteorology, Ionosphere, and Climate (Formosat-3/COSMIC; Anthes et al., 2008).

\section{Data and method}

\subsection{Radio occultation data}

We utilize atmospheric profiles from GPS RO observations to characterize tropical temperature variability in the UTLS region. GPS RO temperature retrievals are characterized by high vertical resolution (from about $100 \mathrm{~m}$ in the troposphere (Gorbunov et al., 2004) to about $1.5 \mathrm{~km}$ in the stratosphere (Kursinski et al., 1997)) and high accuracy (0.7 to $1 \mathrm{~K}$ between 8 and $25 \mathrm{~km}$; Scherllin-Pirscher et al., 2011b). Since measurements can be obtained during the day and at night as well as in nearly any meteorological weather conditions, data are available with good coverage in space and time (Anthes, 2011).

RO data used in this study were processed at the Wegener Center for Climate and Global Change (WEGC) using the Occultation Processing System (OPS) version 5.6 (Schwärz et al., 2013). The record consists of 13 years of data extending from January 2002 to December 2014. It includes measurements from CHAMP (2002 to 2008), GRACE (2007 to 2014), SAC-C (2006 to 2011), and Formosat-3/COSMIC (2006 to 2014). Due to the RO measurement principle, these data from different satellites can be merged into a single observational record without the need for explicit calibration or homogenization (Hajj et al., 2004; Schreiner et al., 2007; Foelsche et al., 2011).

However, the number of available RO profiles is not constant over time because from 2002 to 2006 there were only measurements available from CHAMP. During this time period, there were only about $400 \mathrm{RO}$ profiles available between $10^{\circ} \mathrm{S}$ and $10^{\circ} \mathrm{N}$ per month. This number significantly increased after 2006, when more than 5000 tropical RO profiles per month became available (see Fig. 1 of ScherllinPirscher et al., 2011a).

We utilize atmospheric profiles of dry temperature, which is the same as physical temperature if humidity is negligible. Since we investigate temperature variability only above $10 \mathrm{~km}$ where humidity effects are small, dry temperature can be used as a proxy for temperature (Scherllin-Pirscher et al., 2011a). 


\subsection{Additional data sets}

We use information on convection and background winds to evaluate relationships with temperature variability observed in GPS RO data. As a proxy for convective activity we use daily gridded fields of outgoing long-wave radiation (OLR) on a $2.5^{\circ} \times 2.5^{\circ}$ latitude-longitude grid provided by the National Oceanic and Atmospheric Administration (NOAA; Liebmann and Smith, 1996). For quantifying background zonal winds in the tropics we use vertically resolved zonal winds above Singapore, which provide a standard index for the QBO. These monthly mean wind profiles are provided by the Freie Universität Berlin (FUB) and are available on standard pressure levels spanning $100-10 \mathrm{hPa}$. We interpolate these data to a vertical altitude grid assuming a scale height of $7 \mathrm{~km}$ and a surface pressure of $1013 \mathrm{hPa}$.

\subsection{Gridding and spectral analysis}

Tropical $\left(10^{\circ} \mathrm{S}\right.$ to $\left.10^{\circ} \mathrm{N}\right)$ temperature profiles from GPS RO are gridded in longitude, altitude, and time (no further latitudinal gridding). Following Randel and Wu (2005), we calculate daily mean fields with a longitudinal resolution of $\Delta \lambda=30^{\circ}$ and a vertical resolution of $\Delta z=100 \mathrm{~m}$. Since underlying GPS RO profiles have a vertical resolution of $0.1-$ $1.5 \mathrm{~km}$ (see Sect. 2.1), adjacent vertical levels are not fully independent of each other.

Due to the relatively small number of RO measurements before 2006 (when only CHAMP measurements are used), we also include data from 2 neighboring days ( \pm 2 days) and apply a weighted temporal average (Gaussian weighted with a 1-day $e$-folding time). On average, there are approximately six profiles per grid box per day during the CHAMP-only period. This number significantly increased to more than 55 profiles per grid box per day after 2006. Infrequent missing grid points are interpolated using profiles from neighboring (longitude $\times$ time) grid cells. These gridded data can resolve waves with zonal wave numbers of up to 6 . While this sampling strategy accurately resolves traveling planetary waves with periods longer than 10 days, amplitudes of waves with short periods ( $<5$ days) are underestimated or poorly resolved (see Randel and Wu, 2005, for details).

These sampling details are important because they will affect all subsequent calculations. Testing different spatiotemporal resolutions reveals that changing the temporal resolution of the grid cells to only \pm 1 day results in too many empty grid boxes during the CHAMP-only period. However, these tests also reveal that the large-scale temporal evolution is essentially the same before and after 2006, independent of including data from \pm 1 day or \pm 2 days.

To quantify behavior of atmospheric waves, we apply space-time spectral analysis (Hayashi, 1971, 1982) separately at each height level using the entire RO record. The record from January 2002 to December 2014 has a total length of 4748 days. Figure 1 shows the wave number-

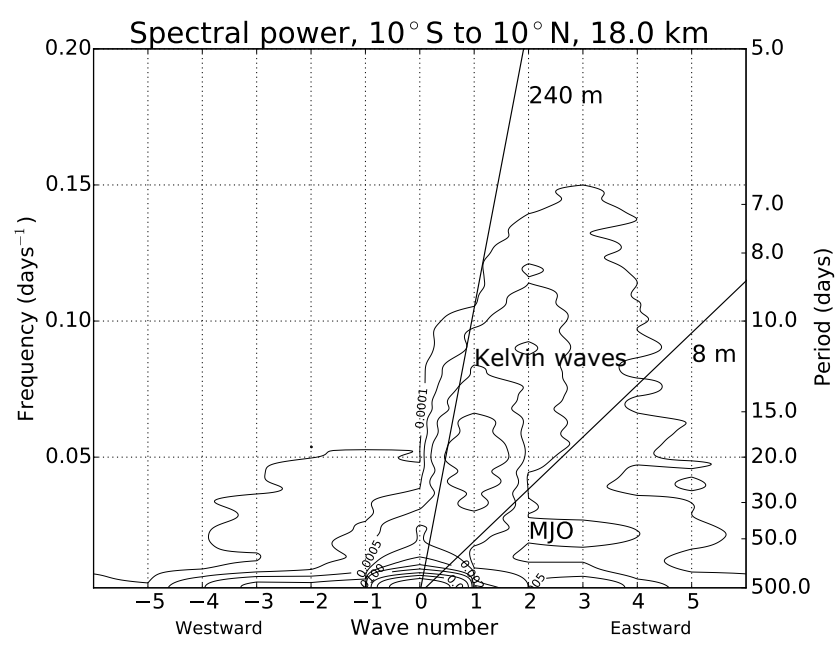

Figure 1. Zonal wave number-frequency power spectrum of RO temperature at $18 \mathrm{~km}$, calculated for the entire record from January 2002 to December 2014. After spectral analysis, the frequency domain of the spectrum is smoothed with a Gaussian filter. Logarithmic contour interval is $(0.0001,0.00025,0.0005,0.001, \ldots, 10,25$, $50) \mathrm{K}^{2}$. The two straight lines indicate equivalent depths of 8 and $240 \mathrm{~m}$.

frequency spectrum of temperature at an altitude of $18 \mathrm{~km}$, based on smoothing the raw spectra in the frequency domain with a Gaussian filter (with an $e$-folding width of 10 frequency bins). The spectrum reveals a maximum for low frequencies and wave number zero, which is largely due to the zonally symmetric annual cycle, driven by the BrewerDobson circulation (BDC) and the QBO. The maximum zonal wave power at $18 \mathrm{~km}$ occurs for eastward-propagating waves with wave numbers 1 and 2 at periods between $\sim 8$ and 30 days. These waves are eastward-propagating equatorial Kelvin waves. A smaller signal related to the MaddenJulian oscillation (MJO) occurs for wave numbers 0 to +4 at approximately 50 days (Madden and Julian, 1971).

Furthermore, we decompose temperature variability into low-frequency and sub-seasonal components, with filtering based on direct Fourier transforms. Low-frequency variations are defined as having periods larger than 100 days. They include contributions of slow and quasi-stationary variations such as the annual cycle and interannual variability (El NiñoSouthern Oscillation (ENSO) and the QBO). Sub-seasonal variability (periods shorter than 100 days) essentially contains signals of the MJO and equatorial waves (e.g., Wheeler and Kiladis, 1999; Ern et al., 2008). We isolate Kelvin-wave activity by selecting wave numbers $k=+1$ to +6 , periods from 4 to 30 days, and equivalent depths from 8 to $240 \mathrm{~m}$. After filtering, reverse fast Fourier transformations (FFTs) are applied to reconstruct atmospheric variability associated with individual types of waves. In order to investigate temporal variations of Kelvin-wave activity we apply wavelet anal- 

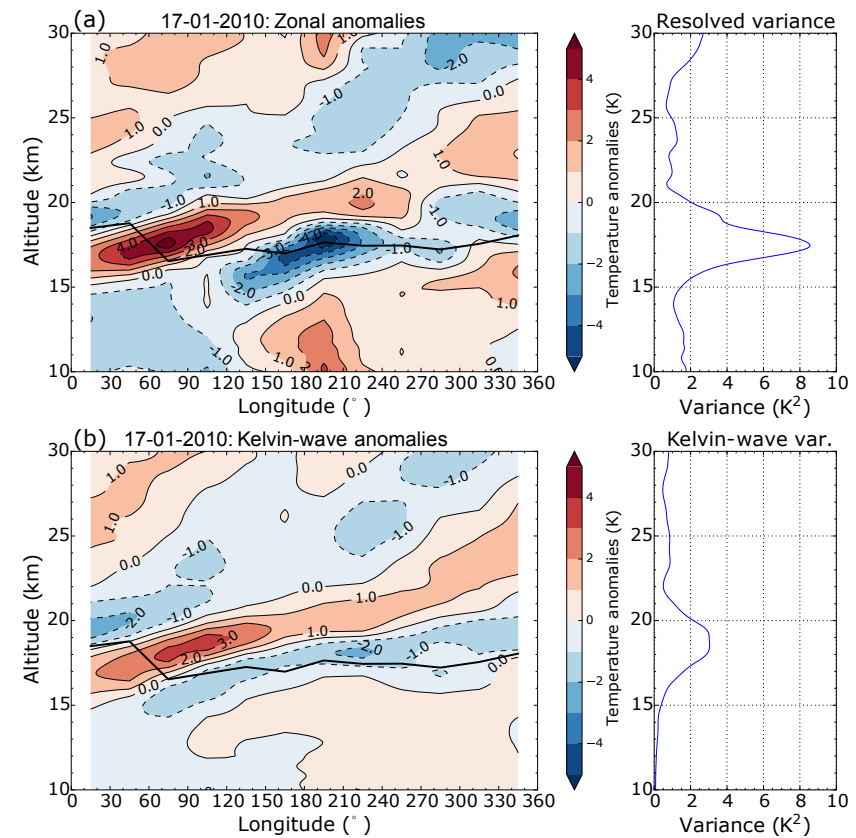

Figure 2. Zonal- (top) and Kelvin-wave (bottom) temperature anomalies as a function of longitude and altitude from 17 January 2010. The black thick line indicates the lapse-rate tropopause. Vertical profiles of associated zonal mean variances are plotted on the right-hand side of each panel.

ysis as described by Torrence and Compo (1998) using the Morlet wavelet basis function.

\section{Results and discussion}

\subsection{Spatial and temporal characteristics of temperature variability}

As an example, the zonal structure of the tropical temperature anomaly from GPS RO is shown for 1 day in January 2010 along with the behavior isolated for Kelvin waves (Fig. 2). The Kelvin wave captures much of the structure over 15$30 \mathrm{~km}$, where both patterns show an eastward phase-tilt with a height that is a characteristic feature of upward-propagating Kelvin waves (e.g., Wheeler et al., 2000; Ryu et al., 2008). The strongest amplitudes are observed near the tropopause, where the magnitude of zonal anomalies (i.e., anomalies relative to the daily mean zonal mean) exceeds $5 \mathrm{~K}$ and that of Kelvin waves exceeds $2 \mathrm{~K}$. The strong positive temperature anomaly close to $75^{\circ} \mathrm{E}$ is associated with a depression of the tropopause altitude of almost $2 \mathrm{~km}$. The vertical profile of associated variance in Fig. 2 shows a peak of resolved variance $\left(>8 \mathrm{~K}^{2}\right)$ between 17 and $18 \mathrm{~km}$. Kelvin-wave variance shows a maximum at 18 to $19 \mathrm{~km}$, but it is only about a quarter of resolved variance $\left(>2 \mathrm{~K}^{2}\right.$ ), while a large fraction of the variance in the stratosphere is associated with Kelvin waves. Temperature anomalies in the troposphere do not ex- hibit a phase-tilted structure (Fig. 2a). Rather, the patterns show warm anomalies extending into the upper troposphere (around $14 \mathrm{~km}$ ) and centered close to the date line. Kelvinwave activity is weak in this region (Fig. 2b).

Figure 2 reveals that Kelvin waves may contribute only a fraction of variability in the tropical tropopause region on an individual daily basis, leading to the question of what else contributes to total zonal temperature variability in this region. Figure 3 shows temporal evolution of zonal temperature anomalies (relative to daily mean zonal mean) from November 2009 to February 2011 at $18 \mathrm{~km}$. Sub-seasonal and low-frequency components of the anomalies are also shown. Both zonal and sub-seasonal anomalies (Fig. 3a, b) highlight eastward-propagating wave events linked to Kelvin waves. Roughly half of the variance in the sub-seasonal anomaly is explained by Kelvin waves at this level. Enhanced Kelvin-wave activity is found in January, May, and August to October 2010.

Quasi-stationary low-frequency variations are also a large part of total temperature variability near the tropopause (Fig. 3c). These are tied to low-frequency variations in tropical convection (Randel et al., 2003; Gettelman and Birner, 2007) and have annual and interannual variations near the tropopause. At $18 \mathrm{~km}$, negative temperature anomalies are evident east of the region of enhanced convection. While maximum low-frequency temperature variance is usually found in boreal winter (see below), some differences in anomaly patterns are found between 2009-2010 and 20102011 due to ENSO. A moderate El Niño event in late 2009 and early 2010 shifted convective regions towards the eastern equatorial Pacific, while a moderate La Niña event in late 2010 and early 2011 shifted equatorial convective regions to the western part of the Pacific Basin. The negative temperature anomalies at $18 \mathrm{~km}$ correspond well with the shift of convective regions caused by different phases of ENSO.

The annual cycle is an important component in lowfrequency variations near the tropopause. Temporal and spatial characteristics of the mean annual cycle of low-frequency temperature anomalies (averaged over all years of data) are shown in Fig. 4. At an altitude of $18 \mathrm{~km}$, the largest temperature anomalies are observed from November to May, with strong negative anomalies east of the convective regions of the maritime continent and over the western Pacific (approximately 120 to $210^{\circ} \mathrm{E}$ ). A second but significantly weaker temperature minimum is observed above South America (close to $285^{\circ} \mathrm{E}$ ).

The zonal cross-sections of low-frequency temperature anomalies in December-January-February (DJF, Fig. 4b) and June-July-August (JJA, Fig. 4c) reveal that maximum temperature anomalies occur near the tropopause (in DJF) or slightly below (in JJA). Positive temperature anomalies in the troposphere coincide with negative anomalies close to the tropopause and vice versa. The transition between warming and cooling occurs near $14 \mathrm{~km}$, roughly at the level of zero radiative heating (Gettelman and Forster, 2002). In DJF, neg- 
(a) Zonal temperature anomalies at $18.0 \mathrm{~km}$

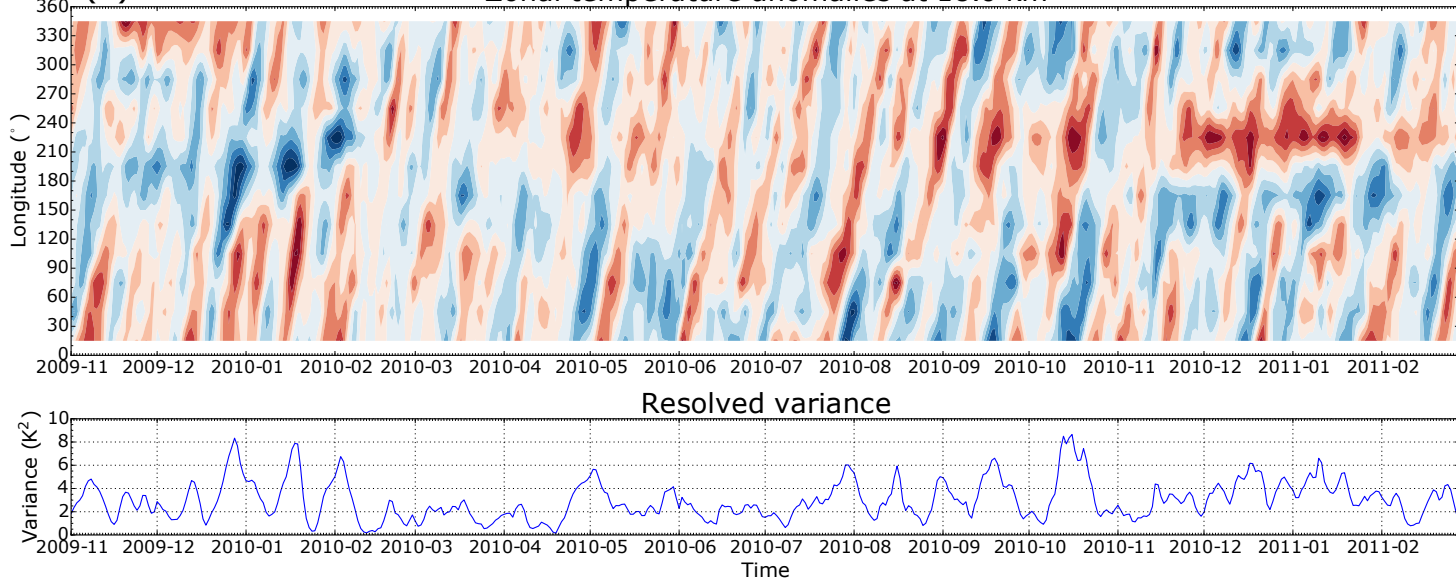

(b)

Sub-seasonal temperature anomalies at $18.0 \mathrm{~km}$

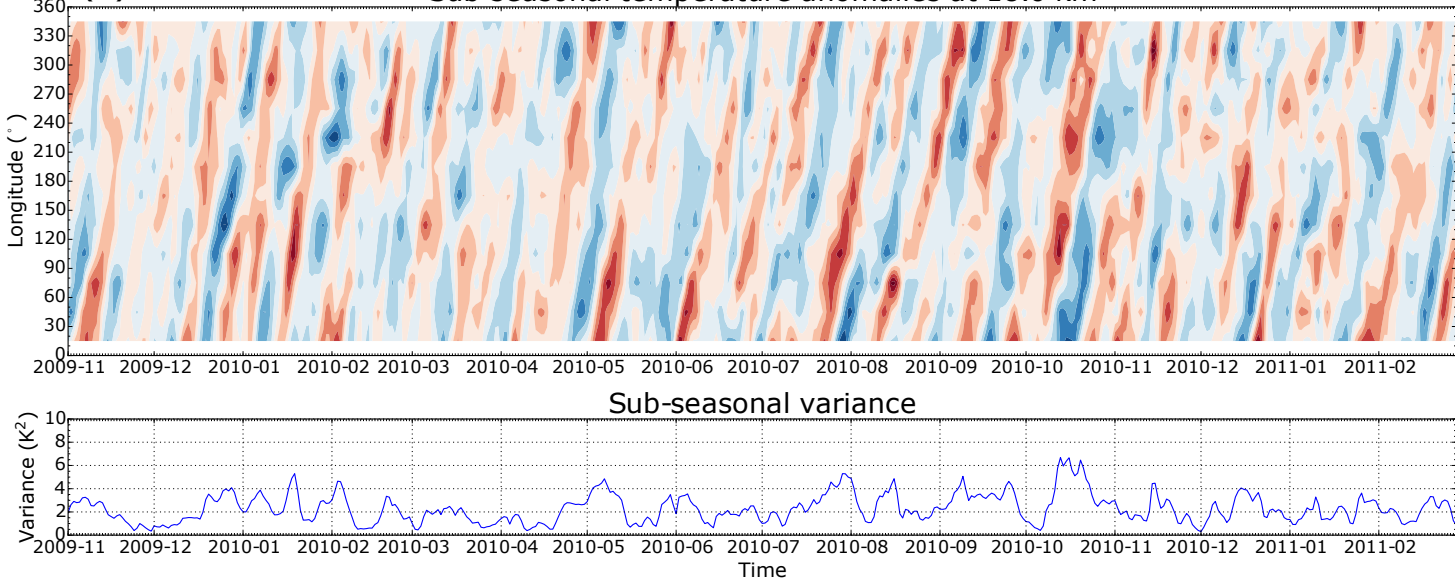

(c)

Low-frequency temperature anomalies at $18.0 \mathrm{~km}$

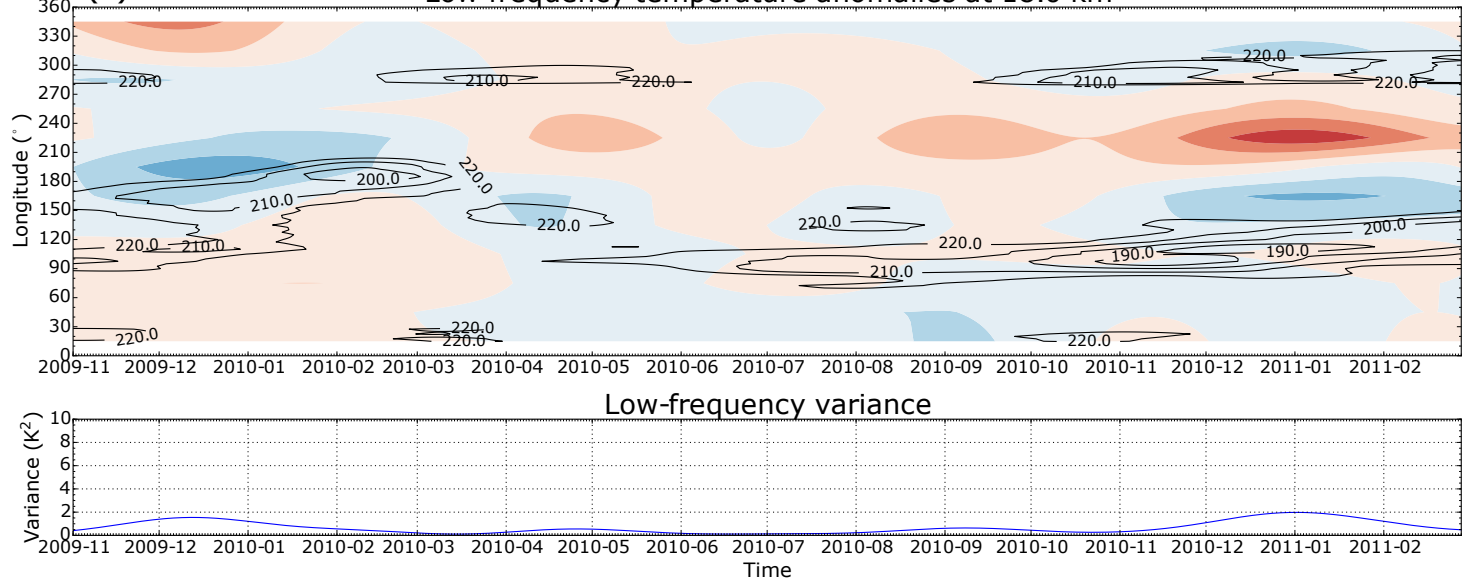

Figure 3. Hovmöller diagrams of zonal, sub-seasonal, and low-frequency temperature anomalies (top to bottom) at an altitude of $18 \mathrm{~km}$ from November 2009 to February 2011. Temporal evolutions of associated zonal mean variances are plotted at the bottom of each panel. Contour lines in panel (c) denote strong convection (low-frequency filtered OLR $\left(\mathrm{W} \mathrm{m}^{-2}\right.$ ) averaged over $10^{\circ} \mathrm{S}$ to $\left.10^{\circ} \mathrm{N}\right)$.

ative temperature anomalies close to the tropopause (which tilt slightly eastward with height) are distinctively larger than in JJA, and this is reflected in the seasonal variation at $18 \mathrm{~km}$ seen in Fig. 4a.
These results show that quasi-stationary patterns are primarily responsible for differences between zonal- and Kelvin-wave anomalies in the tropical tropopause region as shown in Fig. 2. 

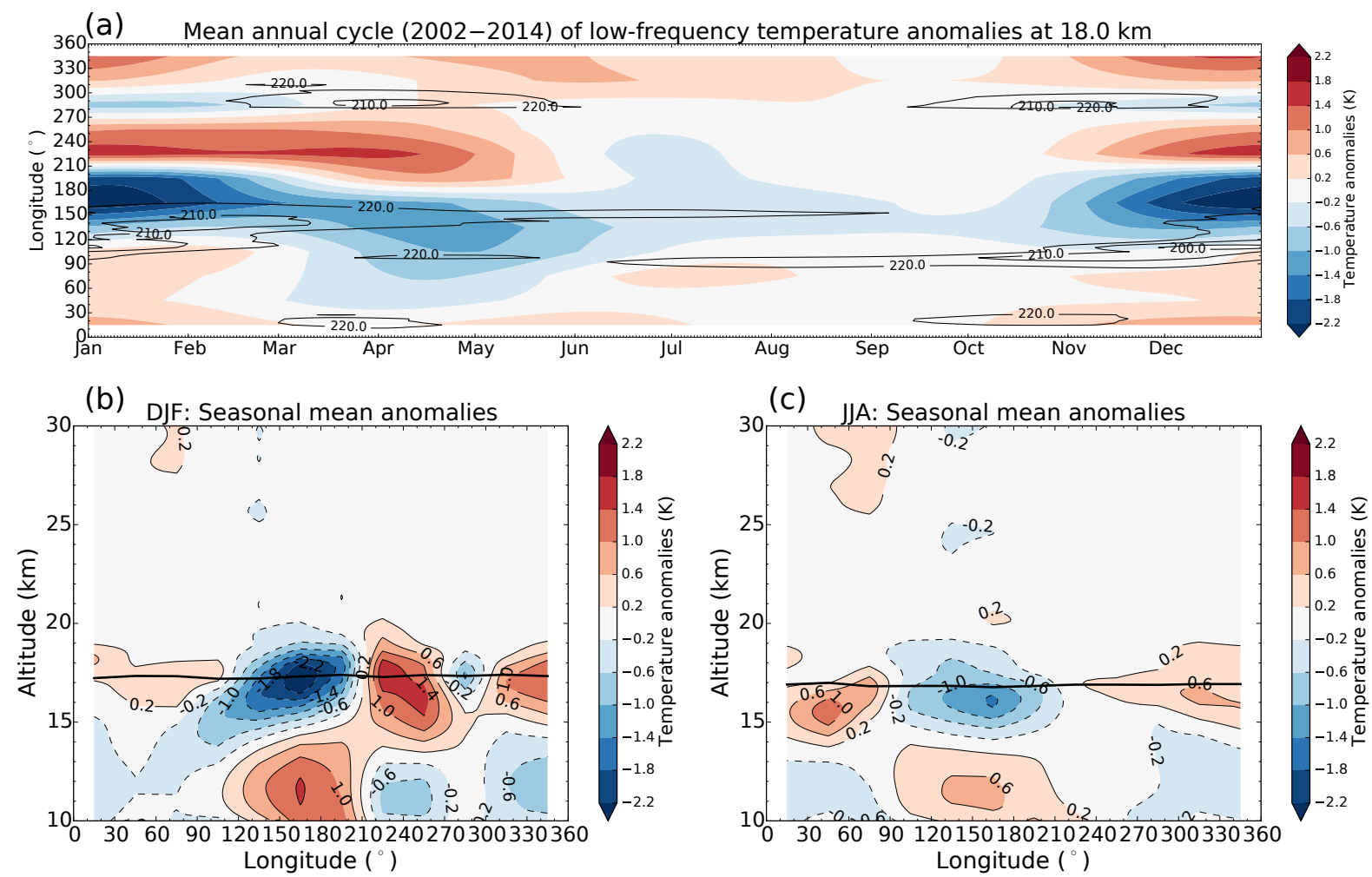

Figure 4. Hovmöller diagram of the mean annual cycle of low-frequency temperature anomalies at an altitude of $18 \mathrm{~km}$ (top panel) and associated seasonal mean anomalies as a function of longitude and altitude in DJF and JJA (bottom panels). Contour lines in panel (a) denote climatological strong convection (mean annual cycle of low-frequency filtered OLR, $\mathrm{W} \mathrm{m}^{-2}$ ). The black thick line in panels (b) and (c) indicates the lapse-rate tropopause.

\subsection{Long-term characteristics of temperature variability}

Long-term variability in these data is analyzed based on daily vertical profiles of zonal mean variances for the entire RO record from January 2002 to December 2014. Figure 5 shows time series for resolved variance and Kelvin-wave variance for the long-term record. To put temperature variance in the context of background conditions, the top panel of Fig. 5 shows zonal mean wind speed above Singapore, which highlights downward-propagating QBO variations.

In the lower and middle stratosphere (above approximately $20 \mathrm{~km}$ ), there is a strong modulation of temperature variance from the QBO. Enhanced temperature variance is observed during the westerly shear phase of the QBO (where the QBO winds switch from easterly to westerly with altitude), while this is not evident during the easterly shear phase. Since variance is mainly caused by sub-seasonal fluctuations, enhanced variance is found in both resolved variance and Kelvin-wave variance. In fact, Kelvin-wave activity dominates the gridded variance at these levels.

A relative maximum in variance is found in the tropical tropopause region between approximately 16 and $20 \mathrm{~km}$ in Fig. 5b. However, temporal evolution of the variance is not associated with the QBO but shows an annual cycle with maxima in boreal winter (see Fig. 4). Kelvin waves contribute to enhanced variance near the tropopause but their amplitudes do not exhibit any distinct periodicities (as shown below). Small Kelvin-wave variance is found below the tropopause.

Figure 5b shows distinctively larger temperature variability before 2006 compared to after 2006. This behavior is related to the smaller number of RO measurements before 2006 (during the CHAMP-only period). A similar jump is less evident in Kelvin-wave variance. We have tested the effect of GPS RO sampling on gridded temperature variance, based on sub-sampling the period with dense observations (after 2006) using just one satellite (Formosat-3/COSMIC flight model 1 (FM-1) from July 2006 to December 2014). Comparisons of variances obtained from all RO measurements with the subsampled set of RO measurements (Fig. 6) show that resolved variance and sub-seasonal variance estimates are sensitive to the number of data included in the samples, with higher variances for sampling by only one GPS RO satellite. This can be explained by noting that much of sub-seasonal variance is related to sub-grid-scale (smaller than $30^{\circ}$ ) variation (as shown in Randel and Wu, 2005), which is under-sampled by one satellite. This means that the relatively large variance be- 

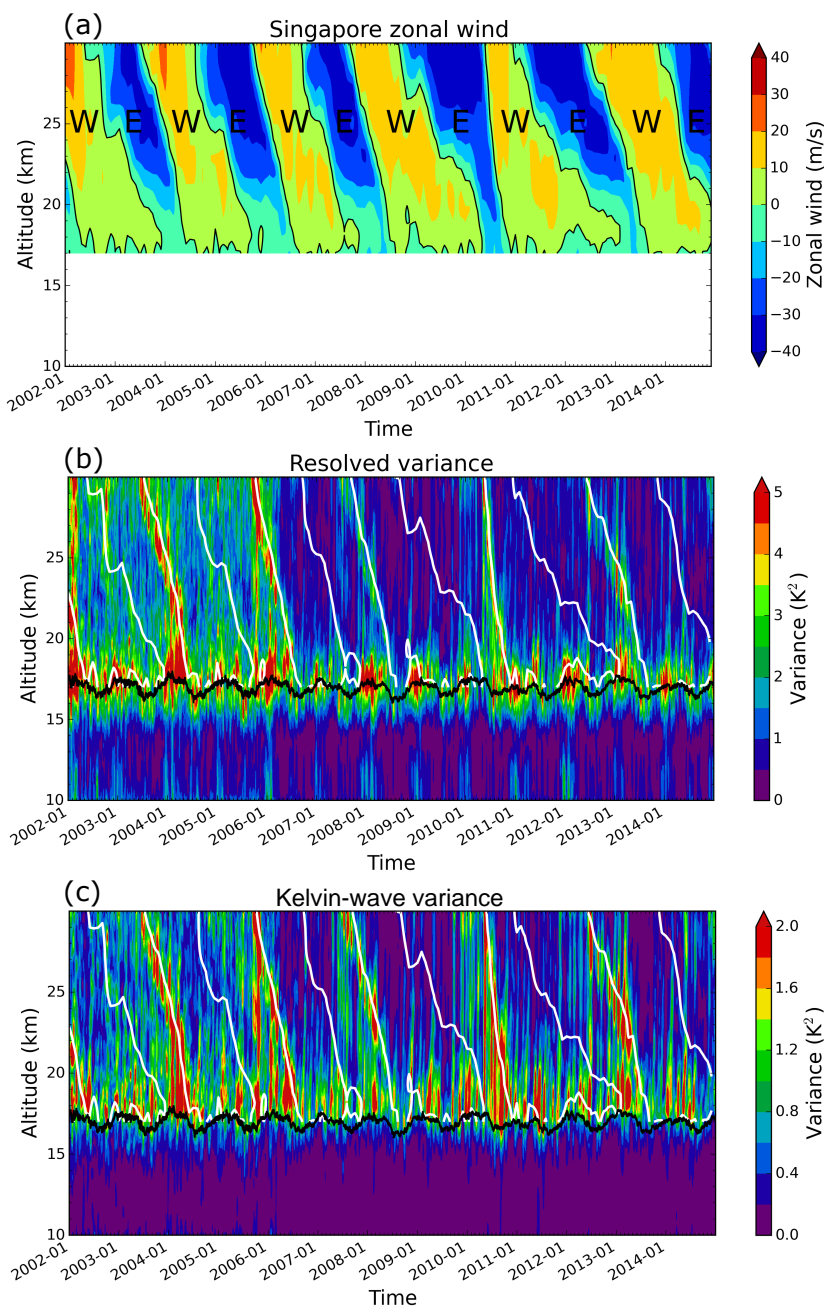

Mean of resolved variance (green), low-frequency variance (blue), sub-seasonal variance (orange), and Kelvin-wave variance (red) as a function of altitude from 15 to $25 \mathrm{~km}$. Statistics of variances based on all satellite measurements are shown with thick lines, and statistics of variances based on single satellite measurements are shown with thin lines. All statistics were obtained from January 2007 to December 2014.

Comparison of mean vertical profiles of resolved variance, low-frequency variance, and sub-seasonal variance as well as Kelvin-wave variance obtained from all satellite measurements (thick profiles in Fig. 6) shows the relative importance of individual components. In the lower and middle stratosphere (above $\sim 19 \mathrm{~km}$ ), low-frequency variance is negligible, and variance is mainly caused by sub-seasonal fluctuations. Kelvin waves dominate these sub-seasonal fluctuations, and they contribute approximately $65 \%$ of the resolved variance in the lower and middle stratosphere. Larger differences between resolved variance and sub-seasonal variance are observed below $19 \mathrm{~km}$. Even though both types of variance peak somewhere between 17.5 and $18 \mathrm{~km}$, subseasonal variance is significantly smaller than resolved variance, with means of 2 and $3 \mathrm{~K}^{2}$, respectively. Low-frequency variance also increases below $19 \mathrm{~km}$ and reaches a maximum of about $1.2 \mathrm{~K}^{2}$ at $17 \mathrm{~km}$. This is due to the influence of quasistationary waves in boreal winter (see Figs. 3 and 4).

Kelvin-wave activity peaks near $18 \mathrm{~km}$, where its mean variance amounts to approximately $1.2 \mathrm{~K}^{2}$. This is about half of sub-seasonal variance. Ryu et al. (2008) suggest that the height of maximum Kelvin-wave activity slightly above the tropical tropopause is due to the rapid increase of static stability above the tropopause and only weak dependence on background wind speed in this region. Kelvin-wave activity decreases below $18 \mathrm{~km}$; near the tropopause at $17 \mathrm{~km}$ it is 

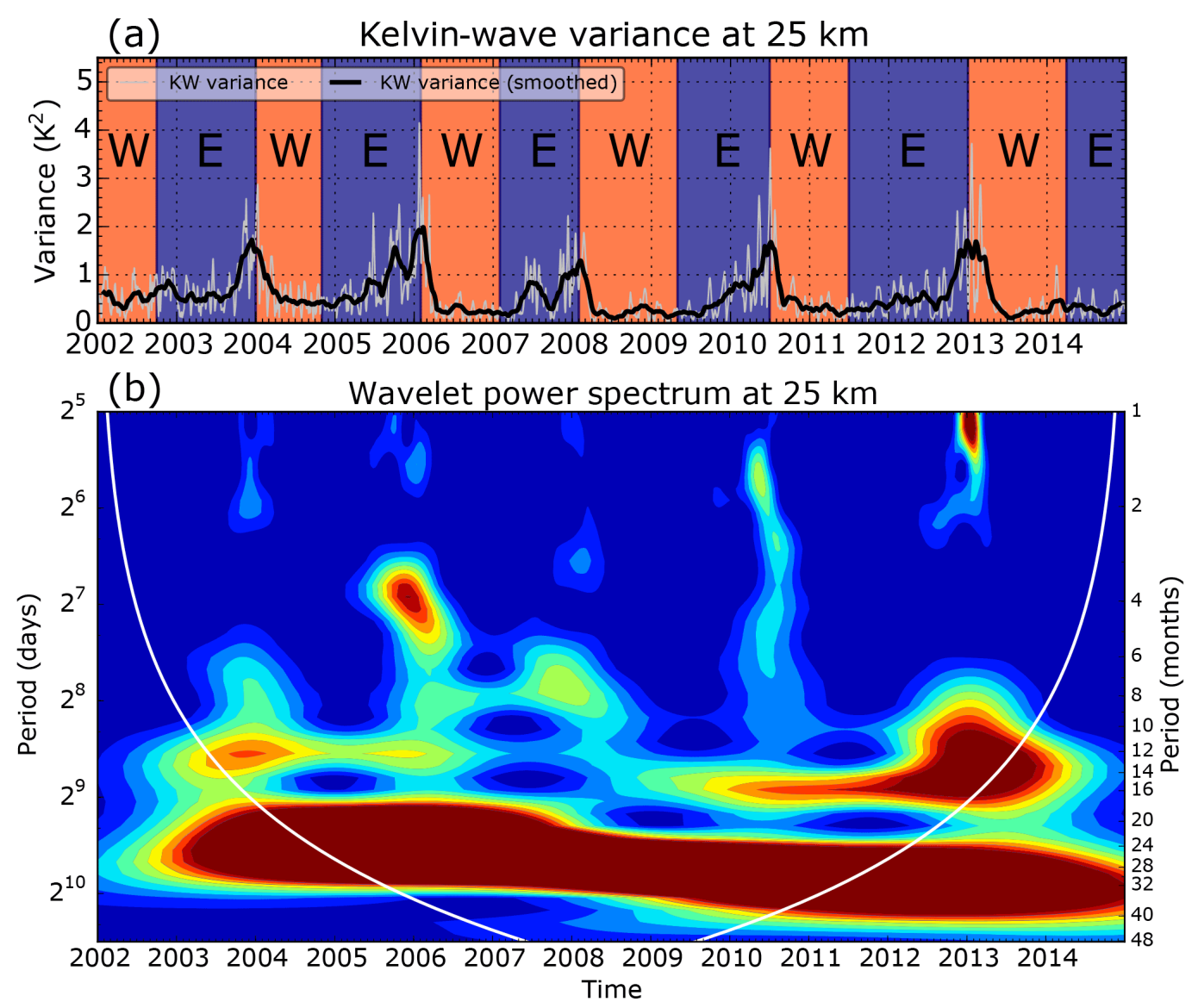

Figure 7. Time series of daily Kelvin-wave variance (thin gray) and smoothed Kelvin-wave variance (thick black) from January 2002 to December 2014 at an altitude of $25 \mathrm{~km}$ (top panel). Orange and blue background colors indicate westerlies (W) and easterlies (E) at $25 \mathrm{~km}$ above Singapore. Wavelet power spectrum of daily Kelvin-wave variance at $25 \mathrm{~km}$ (bottom panel). The white line indicates the cone of influence. The period shown on the right $y$ axis (period in months) is calculated assuming 30 days per month.

only $50 \%$ of sub-seasonal variance, and less than $40 \%$ below.

\subsection{Temporal variations in Kelvin-wave activity}

In the lower and middle stratosphere, Kelvin-wave activity is at a maximum during the westerly shear phases of the QBO (see Fig. 5c). This behavior is highlighted in Fig. 7, showing temporal variations of daily Kelvin-wave variance at $25 \mathrm{~km}$. The smoothed time series is obtained by applying a 61-day moving average. Kelvin-wave variance in Fig. 7a shows amplitude variations that are strongly modulated by the QBO, with enhanced wave activity in periods of transition from easterly to westerly stratospheric wind (westerly shear zones). Similar results have been found by Randel and Wu (2005); Ern et al. (2008); Alexander and Ortland (2010); Flannaghan and Fueglistaler (2013). These peaks in Kelvinwave activity are expected since Kelvin-wave energy is accumulated below the critical level, which is located near the zero-wind line. The wavelet power spectrum (Fig. 7b) con- firms that most power is concentrated at periods from 24 to 32 months, which correspond to the period of the QBO. Some wavelet power at periods between 12 and 16 months is associated with some smaller peaks of wave activity, in particular at the end of the time series.

While Kelvin-wave activity is clearly associated with the QBO above $20 \mathrm{~km}$, variability in the vicinity of the tropical tropopause shows less regularity. Figure 8 shows detailed time variations of daily Kelvin-wave variance between 16 and $20 \mathrm{~km}$. Weak Kelvin-wave activity is observed at $16 \mathrm{~km}$. The wavelet power spectrum (not shown) reveals enhanced power at a period of approximately 12 months from 2003 to 2007 and from 2010 to 2012, which is in agreement with Alexander and Ortland (2010), who attributed this annual variation to the effects of the background wind and stability on Kelvin-wave propagation in the tropical tropopause layer.

Kelvin-wave activity reaches maximum amplitude around 18-19 km (see Fig. 6), and variability between 18 and $20 \mathrm{~km}$ is highly correlated across these levels. The peak in early 2004, which is the largest in the GPS RO record, is evident 


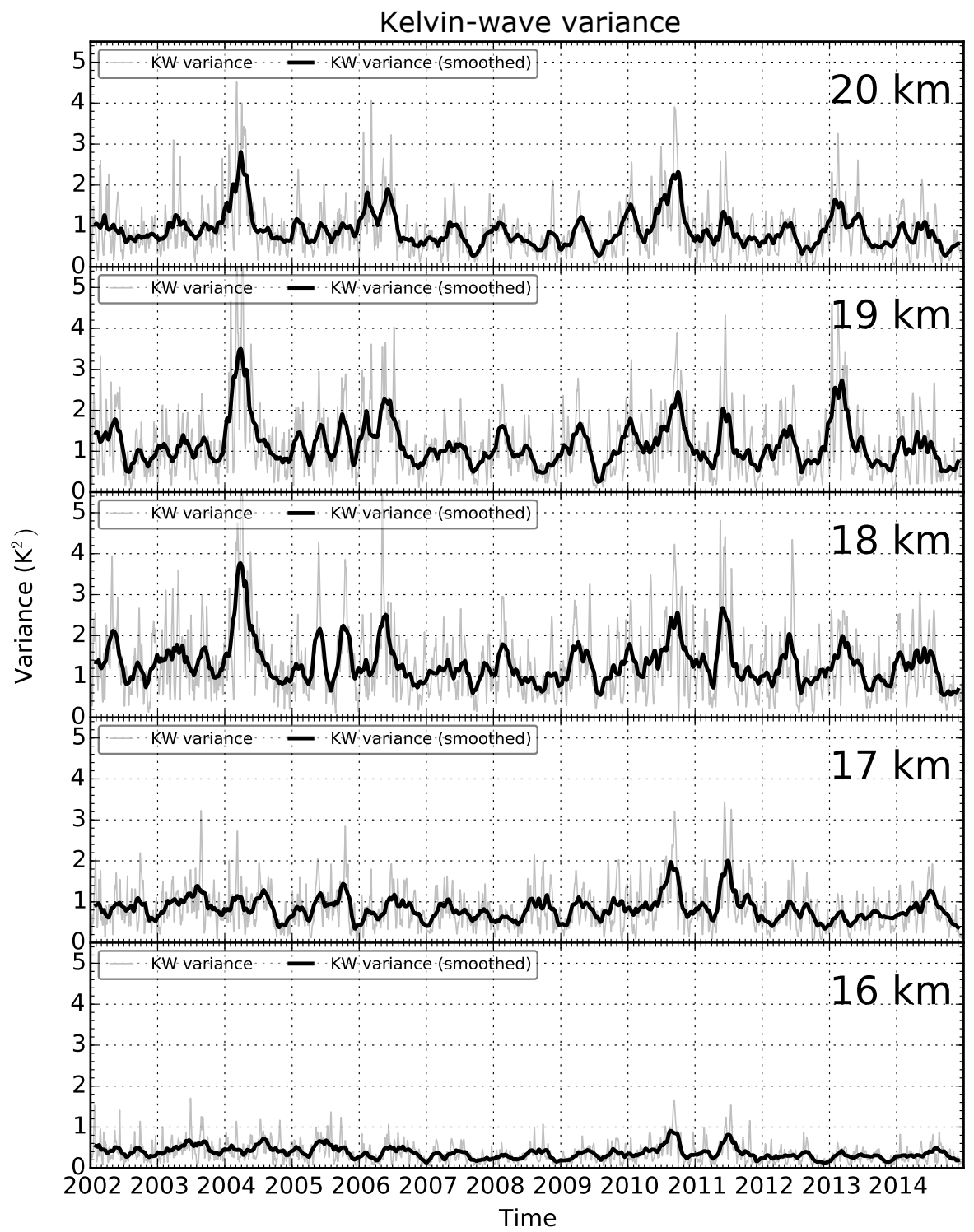

Figure 8. Time series of daily Kelvin-wave variance (thin gray) and smoothed Kelvin-wave variance (thick black) from January 2002 to December 2014 for every kilometer between 20 (top) and $16 \mathrm{~km}$ (bottom).

at each level. In general, peaks of enhanced Kelvin-wave activity are irregularly distributed in time.

To assess whether this temporal variability should be attributed to temporal variations of the tropopause rather than to Kelvin-wave activity itself, we calculated Kelvinwave variance in cold-point tropopause coordinates. Figure 9 shows results at the cold-point tropopause and $2 \mathrm{~km}$ above. Comparison to Fig. 8 shows very similar temporal evolutions. The time series at the tropopause and $2 \mathrm{~km}$ above (Fig. 9) are virtually similar to those at 17 and $19 \mathrm{~km}$ in altitude coordinate (Fig. 8), respectively. Again, no clear periodicity of Kelvin-wave activity can be found.

Figure 10 shows the wavelet power spectrum for the Kelvin-wave amplitudes at $19 \mathrm{~km}$. There is a peak in wavelet power in boreal spring 2004 at a period of approximately 1 year, linked to the maximum wave activity in early 2004, together with two smaller peaks in boreal spring 2003 and 2005 (see Figs. 8 and 11). Maximum wave activity in 2004 could be related to the QBO westerly shear phase (see Fig. 5), although other periods of westerly shear near the tropopause do not show such large wave amplitudes.

Enhanced wavelet power is also observed from 2009 to 2013. It has a period of approximately 9 months, which slightly shifts towards longer periods (about 1 year) at the end of the time series. The approximately 9 -month period is caused by enhanced Kelvin-wave activity in April 2009, January 2010, October 2010, June 2011, June 2012, and February 2013 as observed in Fig. 8. This 9-month periodicity is 


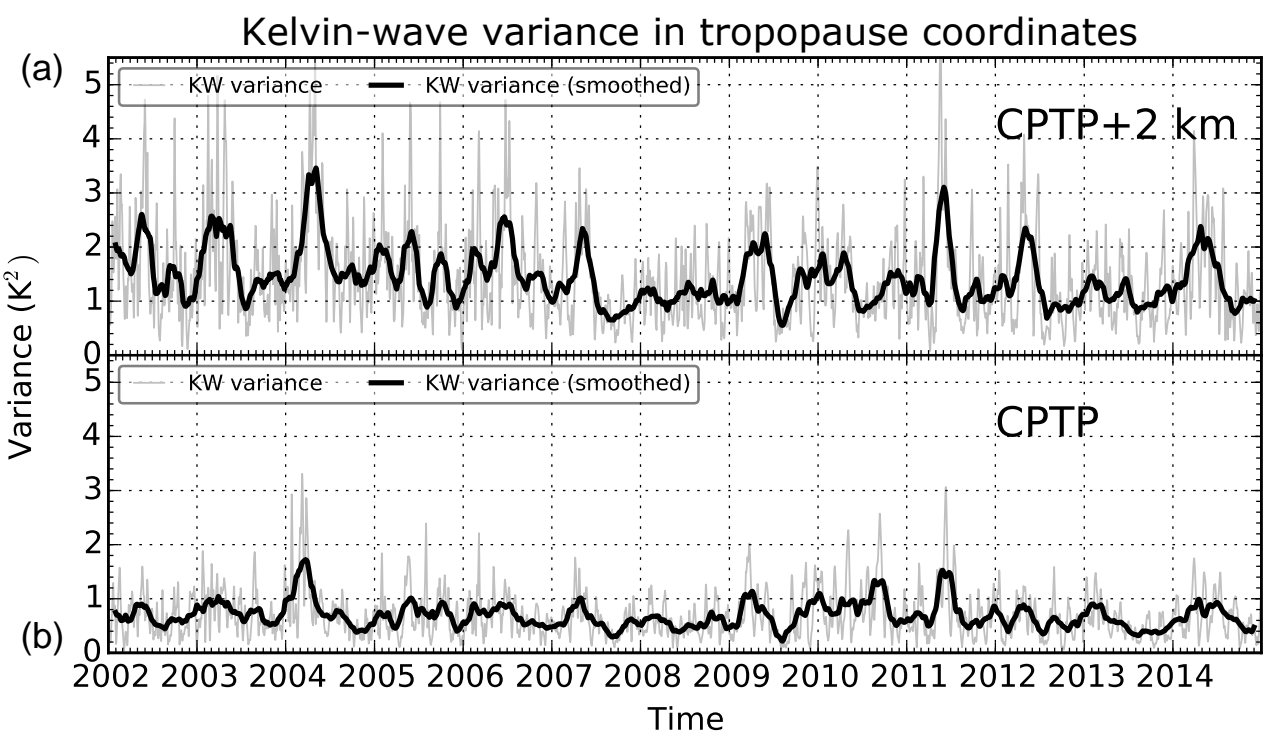

Figure 9. Time series of daily Kelvin-wave variance (thin gray) and smoothed Kelvin-wave variance (thick black) from January 2002 to December 2014 at the cold-point tropopause (bottom) and $2 \mathrm{~km}$ above (top).

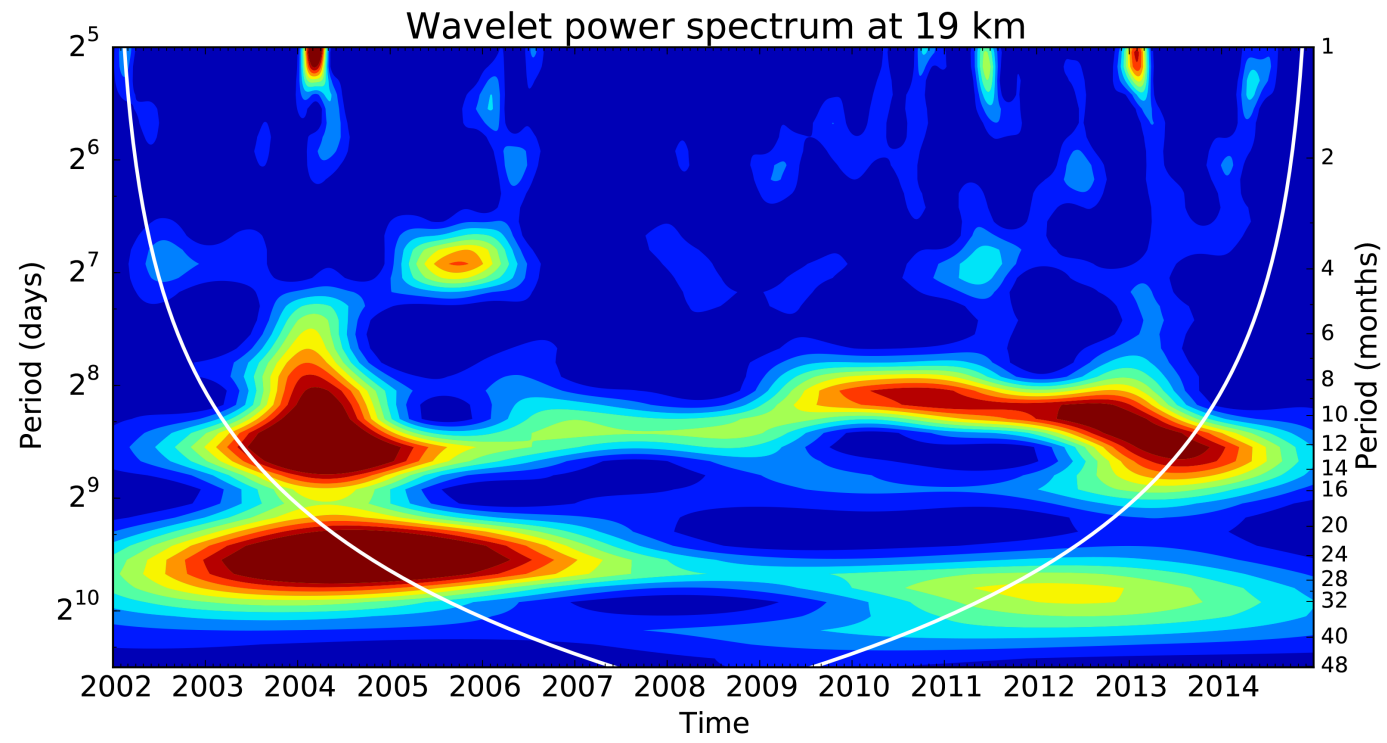

Figure 10. Wavelet power spectrum of daily Kelvin-wave variance at $19 \mathrm{~km}$ from January 2002 to December 2014. The white line indicates the cone of influence. The period shown on the right $y$ axis (period in months) is calculated assuming 30 days per month.

not observed from 2002 to 2008 . The use of a shorter observational record (such as the Formosat-3/COSMIC record from 2006 onward) could therefore lead to a misleading interpretation of the month-to-month variability of Kelvinwave activity.

What causes the month-to-month variability of Kelvinwave activity near the tropopause? Theoretical and modeling studies and previous observational studies (cited above) suggest that Kelvin waves should be influenced by convective forcing and changes in background winds and stability, and hence we investigated these quantities to explain the variations seen in Figs. 8 and 9. An example of the relationship with convective forcing is shown in Fig. 11, showing time series of Kelvin-wave variance at $19 \mathrm{~km}$ and time series of zonal variances of high-pass-filtered OLR data between $10^{\circ} \mathrm{S}$ and $10^{\circ} \mathrm{N}$. These high-pass-filtered OLR data are obtained by applying a 100-day Fourier filter at each grid point. Large zonal variances indicate enhanced variability from short-term fluctuations and different types of waves 
(a) Kelvin-wave variance at $19 \mathrm{~km}$
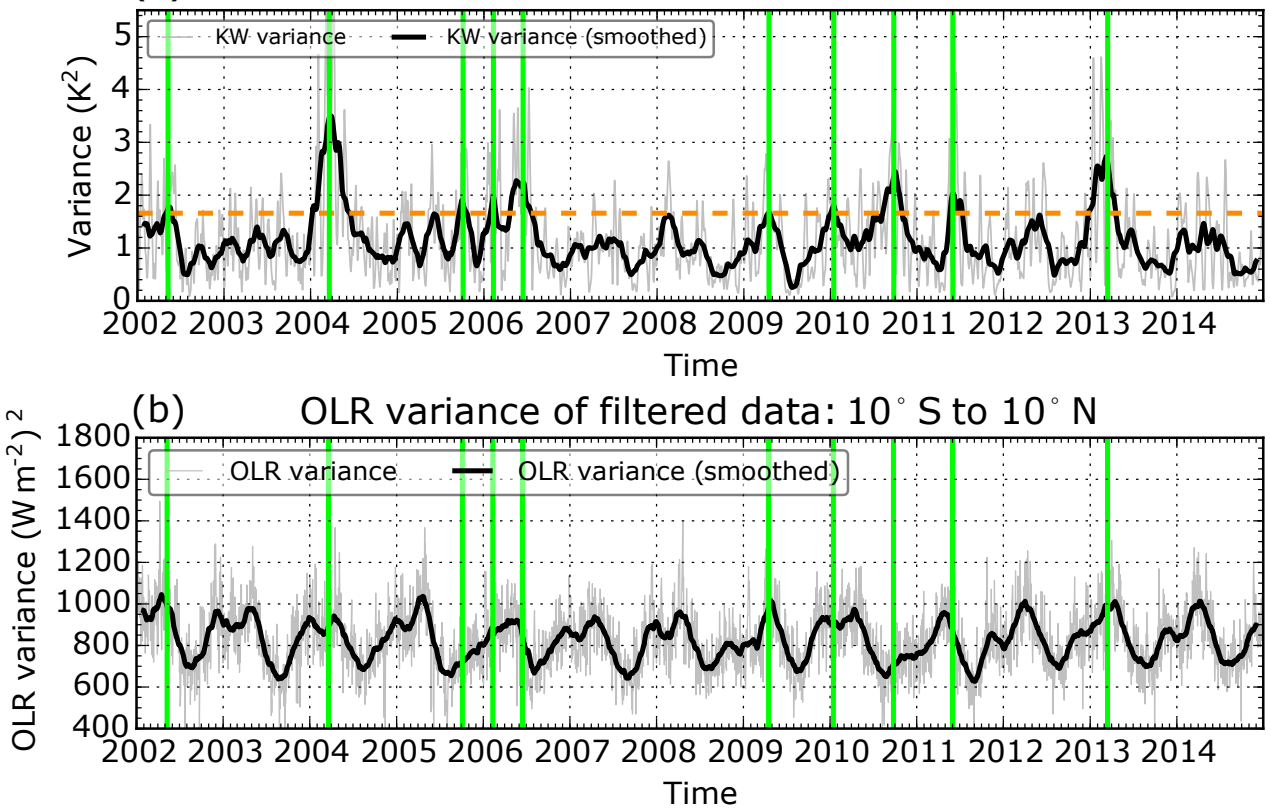

Figure 11. Time series of daily Kelvin-wave variance (thin gray) and smoothed Kelvin-wave variance (thick black) at $19 \mathrm{~km}$ (top panel) and time series of daily variances of high-pass-filtered OLR data between $10^{\circ} \mathrm{S}$ and $10^{\circ} \mathrm{N}$ (bottom panel). Green lines indicate points of time with smoothed Kelvin-wave variance outside of 1 standard deviation $\left(1.66 \mathrm{~K}^{2}\right.$, indicated by the dashed yellow line).

similar to high-pass-filtered temperature anomalies shown in Fig. 3b.

Zonal variance of filtered OLR data (Fig. 11b) has a pronounced annual cycle, which peaks in boreal spring (AprilMay). Almost every year, there is a second peak in fall or early winter (November-December). Several peaks in Kelvin-wave activity match peaks in OLR variance. However, there are also several mismatches, where OLR variability is large but Kelvin-wave activity is weak (spring 2003, 2005, 2007, and 2014) and also several mismatches were OLR variability is small but Kelvin-wave activity is large (fall 2006, fall 2010). Another discrepancy between Kelvin-wave activity and OLR variability is that the former has strong month-to-month variability, while the latter peaks have similar amplitude every year. Discrepancies between equatorial wave activity close to the tropopause and wave activity in tropospheric convection have also been found by Alexander et al. (2008) and Alexander and Ortland (2010). Suzuki and Shiotani (2008) suggested that the background zonal wind field modulates the propagation of these waves. This was also found by Ryu et al. (2008), who showed that background zonal wind plays an important role in modulating Kelvin waves close to the tropical tropopause. More recently, Flannaghan and Fueglistaler (2013) showed that seasonal and interannual variability of Kelvin-wave propagation is dominated by the variability in the background wind field. However, we have explored this behavior and do not find any evident relationships between Kelvin-wave amplitudes and changes in winds near the tropopause (based on Singapore winds). More detailed calculations may need to follow Flannaghan and Fueglistaler (2013) and use the full background structure along the waves' trajectories to determine their amplitudes.

\section{Summary and conclusions}

Using 13 years of GPS radio occultation (RO) data, we have investigated tropical temperature variability and associated Kelvin-wave activity in the upper troposphere and lower stratosphere (UTLS) region. In this region, RO measurements are characterized by high accuracy and precision as well as high vertical resolution, which makes these data ideal for characterizing temperature oscillations with short vertical wavelengths.

We have constructed daily gridded temperature fields in the tropics $\left(10^{\circ} \mathrm{N}\right.$ to $\left.10^{\circ} \mathrm{S}\right)$ from January 2002 to December 2014 and examined variability on fast and slow timescales (periods shorter and longer than 100 days). Eastwardtraveling Kelvin waves are an obvious feature in these data (e.g., Fig. 1), and we use space-time spectral analysis to isolate Kelvin waves with zonal waves +1 to +6 , periods of 4 to 30 days, and equivalent depths of 8 to $240 \mathrm{~m}$.

The largest zonal temperature variability ("resolved variance") was found in the tropical tropopause region close to the tropopause. Maximum variance $\left(3 \mathrm{~K}^{2}\right)$ was found between 17.5 and $18 \mathrm{~km}$. Quasi-stationary waves with periods 
larger than 100 days are an important part of zonal variability in this region, and there is a strong annual cycle with maximum amplitude during boreal winter (Fig. 4). Low-frequency interannual variability is also associated with the El NiñoSouthern Oscillation (ENSO). These low-frequency waves are strongly tied to convection (Figs. 3 and 4). Tropospheric temperature is higher eastward of regions of strong convective activity (e.g., above the maritime continent and the western Pacific). ENSO activity slightly shifts these centers of convection and temperature response. Transition from warming to cooling occurs close to $14 \mathrm{~km}$ and distinct negative anomalies are observed east of the convective region close to the tropopause. Low-frequency wave activity maximizes near the tropical tropopause $\left(1.2 \mathrm{~K}^{2}\right.$ at approximately $\left.17 \mathrm{~km}\right)$.

Sub-seasonal waves (periods $<100$ days) dominate zonal temperature variability above the tropical tropopause. Maximum wave activity $\left(2 \mathrm{~K}^{2}\right)$ was found slightly below $18 \mathrm{~km}$. In the lower and middle stratosphere (above $\sim 20 \mathrm{~km}$ ) this temperature variance is strongly modulated by the QBO, with enhanced wave activity observed during the westerly shear phase of the QBO (Figs. 5 and 7). Transient Kelvin waves are an important part of sub-seasonal waves. They contribute approximately $65 \%$ of the resolved variance above $20 \mathrm{~km}$. Maximum Kelvin-wave activity $\left(1.2 \mathrm{~K}^{2}\right)$ was found at $18 \mathrm{~km}$, decreasing at lower altitudes (to less than $0.4 \mathrm{~K}^{2}$ at $16 \mathrm{~km}$ ).

Another aspect of this study was to investigate longterm (13 years) characteristics of tropical temperature variability. However, the number of available RO measurements is not constant with time but increased significantly in 2006 after the launch of the multi-satellite mission Formosat-3/COSMIC. We quantified the influence of changes in the number of RO measurements and found increased variance in gridded data due to the lack of dense measurements before 2006 (Fig. 6). Therefore, it was not possible to combine daily variances from a single satellite with daily variances from multiple satellites. However, there were relatively small differences for analysis of low-frequency or planetary-scale Kelvin waves, since these were sampled well by even one GPS RO satellite. Hence, we are confident to use the entire 13-year record of RO to investigate Kelvin-wave activity.

In general, Kelvin waves show strong amplitude variations over time. Above $20 \mathrm{~km}$, enhanced Kelvin-wave activity is found during the westerly shear phase of the QBO. However, near the tropopause ( $\sim 16$ to $20 \mathrm{~km})$ peaks of enhanced wave activity are irregularly distributed in time without a distinct periodicity. At $19 \mathrm{~km}$ (close to the level where maximum Kelvin-wave activity occurs) we found six distinct peaks with an approximately 9-month period between 2009 and 2013. This 9-month period, however, was not observed during 2002 and 2008.

We further explored the influence of deep convective activity in the tropical troposphere on Kelvin-wave activity. We found that several peaks in Kelvin-wave activity coincide with peaks of zonal variance of sub-seasonal waves of con- vective activity but other maxima are not evidently related. Also, there are no obvious relationships with zonal winds or stability fields near the tropopause level. Hence the nature of the modulations in Kelvin waves near the tropopause remains poorly understood. One important step towards a better understanding could be to follow Flannaghan and Fueglistaler (2013) and use the full background structure along the waves' trajectories.

\section{Data availability}

The GPS RO data used in this study are publicly available at https://wegcwww.uni-graz.at/publ/wegcpubl/arsclisys/ 2017/RO_2002-01-01T00_00_00-2015-01-01T00_00_ 00_10S-10N.nc. Monthly mean vertical profiles of zonal winds above Singapore can be downloaded at http://www.geo.fu-berlin.de/en/met/ag/strat/produkte/qbo/ and NOAA OLR data are available at https://www.esrl. noaa.gov/psd/data/gridded/data.interp_OLR.html. The time series ends in 2013. Further data can be obtained from esrl.psd.data@noaa.gov upon request.

Author contributions. Barbara Scherllin-Pirscher collected the data, performed the analyses, and wrote the manuscript. William J. Randel and Joowan Kim provided guidance on all aspects of the study and contributed to the text.

Acknowledgement. We are grateful to the UCAR/CDAAC and WEGC RO processing team members. M. Schwärz is especially thanked for OPSv5.6 RO data provision. Furthermore, we want to thank NOAA for providing OLR data and FU Berlin for Singapore zonal winds. We thank F. Ladstädter (WEGC, AT), A. K. Steiner (WEGC, AT), and R. Garcia (NCAR, USA) for helpful comments and input. This work was funded by the Austrian Science Fund (FWF) under research grant T620-N29 (DYNOCC).

Edited by: P. Haynes

Reviewed by: two anonymous referees

\section{References}

Alexander, M. J. and Ortland, D. A.: Equatorial waves in High Resolution Dynamics Limb Sounder (HIRDLS) data, J. Geophys. Res., 115, D24111, doi:10.1029/2010JD014782, 2010.

Alexander, S. P., Tsuda, T., Kawatani, Y., and Takahashi, M.: Global distribution of atmospheric waves in the equatorial upper troposphere and lower stratosphere: COSMIC observations of wave mean flow interactions, J. Geophys. Res., 113, D24115, doi:10.1029/2008JD010039, 2008.

Andrews, D. G., Holton, J. R., and Leovy, C. B.: Middle Atmosphere Dynamics, vol. 40 of International Geophysical Series, Academic Press, 1987. 
Anthes, R. A.: Exploring Earth's atmosphere with radio occultation: contributions to weather, climate and space weather, Atmos. Meas. Tech., 4, 1077-1103, doi:10.5194/amt-4-1077-2011, 2011.

Anthes, R. A., Bernhardt, P. A., Chen, Y., Cucurull, L., Dymond, K. F., Ector, D., Healy, S. B., Ho, S.-P., Hunt, D. C., Kuo, Y.H., Liu, H., Manning, K., McCormick, C., Meehan, T. K., Randel, W. J., Rocken, C., Schreiner, W. S., Sokolovskiy, S. V., Syndergaard, S., Thompson, D. C., Trenberth, K. E., Wee, T.K., Yen, N. L., and Zeng, Z.: The COSMIC/FORMOSAT-3 mission: Early results, B. Am. Meteorol. Soc., 89, 313-333, doi:10.1175/BAMS-89-3-313, 2008.

Baldwin, M. P., Gray, L. J., Dunkerton, T. J., Hamilton, K., Haynes, P. H., Randel, W. J., Holton, J. R., Alexander, M. J., Hirota, I., Horinouchi, T., Jones, D. B. A., Kinnersley, J. S., Marquardt, C., Sato, K., and Takahashi, M.: The Quasi-Biennial Oscillation, Rev. Geophys., 39, 179-229, 2001.

Boehm, M. T. and Verlinde, J.: Stratospheric influence on upper tropospheric tropical cirrus, Geophys. Res. Lett., 27, 3209-3212, doi:10.1029/2000GL011678, 2000.

Das, U. and Pan, C. J.: Strong Kelvin wave activity observed during the westerly phase of QBO - a case study, Ann. Geophys., 31, 581-590, doi:10.5194/angeo-31-581-2013, 2013.

Ern, M. and Preusse, P.: Wave fluxes of equatorial Kelvin waves and QBO zonal wind forcing derived from SABER and ECMWF temperature space-time spectra, Atmos. Chem. Phys., 9, 39573986, doi:10.5194/acp-9-3957-2009, 2009.

Ern, M., Preusse, P., Krebsbach, M., Mlynczak, M. G., and Russell III, J. M.: Equatorial wave analysis from SABER and ECMWF temperatures, Atmos. Chem. Phys., 8, 845-869, doi:10.5194/acp-8-845-2008, 2008.

Flannaghan, T. J. and Fueglistaler, S.: The importance of the tropical tropopause layer for equatorial Kelvin wave propagation, J. Geophys. Res., 118, 5160-5175, doi:10.1002/jgrd.50418, 2013.

Foelsche, U., Scherllin-Pirscher, B., Ladstädter, F., Steiner, A. K., and Kirchengast, G.: Refractivity and temperature climate records from multiple radio occultation satellites consistent within $0.05 \%$, Atmos. Meas. Tech., 4, 2007-2018, doi:10.5194/amt-4-2007-2011, 2011.

Fueglistaler, S., Dessler, A. E., Dunkerton, T. J., Folkins, I., Fu, Q., and Mote, P. W.: Tropical tropopause layer, Rev. Geophys., 47, RG1004, doi:10.1029/2008RG000267, 2009.

Fujiwara, M., Kita, K., and Ogawa, T.: Stratosphere-troposphere exchange of ozone associated with the equatorial Kelvin wave as observed with ozonesondes and rawinsondes, J. Geophys. Res., 103, 19173-19182, doi:10.1029/98JD01419, 1998.

Fujiwara, M., Hasebe, F., Shiotani, M., Nishi, N., Vömel, H., and Oltmans, S. J.: Water vapor control at the tropopause by equatorial Kelvin waves observed over the Galápagos, Geophys. Res. Lett., 28, 3143-3146, doi:10.1029/2001GL013310, 2001.

Fujiwara, M., Suzuki, J., Gettelman, A., Hegglin, M. I., Akiyoshi, H., and Shibata, K.: Wave activity in the tropical tropopause layer in seven reanalysis and four chemistry climate model data sets, J. Geophys. Res., 117, D12105, doi:10.1029/2011JD016808, 2012.

Garcia, R. R. and Salby, M. L.: Transient Response to Localized Episodic Heating in the Tropics, Part II: Far-Field Behavior, J. Atmos. Sci., 44, 499-530, 1987.
Gettelman, A. and Birner, T.: Insights into Tropical Tropopause Layer processes using global models, J. Geophys. Res., 112, D23104, doi:10.1029/2007JD008945, 2007.

Gettelman, A. and Forster, P.: A climatology of the tropical tropopause layer, J. Meteorol. Soc. Jpn., 80, 911-924, 2002.

Gorbunov, M. E., Benzon, H.-H., Jensen, A. S., Lohmann, M. S., and Nielsen, A. S.: Comparative analysis of radio occultation processing approaches based on Fourier integral operators, Radio Sci., 39, RS6004, doi:10.1029/2003RS002916, 2004.

Hajj, G. A., Ao, C. O., Iijima, B. A., Kuang, D., Kursinski, E. R., Mannucci, A. J., Meehan, T. K., Romans, L. J., de la Torre Juarez, M., and Yunck, T. P.: CHAMP and SAC-C atmospheric occultation results and intercomparisons, J. Geophys. Res., 109, D06109, doi:10.1029/2003JD003909, 2004.

Hayashi, Y.: A generalized method of resolving disturbances into progressive and retroprogressive waves by space Fourier and time cross-spectral analyses, J. Meteorol. Soc. Jpn., 49, 125-128, 1971.

Hayashi, Y.: Space-Time Spectral Analysis and its Applications to Atmospheric Waves, J. Meteorol. Soc. Jpn., 60, 156-171, 1982.

Holton, J. R. and Lindzen, R. S.: A note on "Kelvin" waves in the atmosphere, Mon. Weather Rev., 96, 385-386, 1968.

Holton, J. R., Haynes, P. H., McIntyre, M. E., Douglass, A. R., Rood, R. B., and Pfister, L.: Stratosphere-troposphere exchange, Rev. Geophys., 33, 403-439, doi:10.1029/95RG02097, 1995.

Holton, J. R., Alexander, M. J., and Boehm, M. T.: Evidence for short vertical wavelength Kelvin waves in the Department of Energy-Atmospheric Radiation Measurement Nauru99 radiosonde data, J. Geophys. Res., 106, 20125-20129, doi:10.1029/2001JD900108, 2001.

Immler, F., Krüger, K., Fujiwara, M., Verver, G., Rex, M., and Schrems, O.: Correlation between equatorial Kelvin waves and the occurrence of extremely thin ice clouds at the tropical tropopause, Atmos. Chem. Phys., 8, 4019-4026, doi:10.5194/acp-8-4019-2008, 2008.

Kim, J. and Son, S.-W.: Tropical Cold-Point Tropopause: Climatology, Seasonal Cycle, and Intraseasonal Variability Derived from COSMIC GPS Radio Occultation Measurements, J. Climate, 25, 5343-5360, doi:10.1175/JCLI-D-11-00554.1, 2012.

Kursinski, E. R., Hajj, G. A., Schofield, J. T., Linfield, R. P., and Hardy, K. R.: Observing Earth's atmosphere with radio occultation measurements using the Global Positioning System, J. Geophys. Res., 102, 23429-23465, doi:10.1029/97JD01569, 1997.

Liebmann, B. and Smith, C. A.: Description of a Complete (Interpolated) Outgoing Longwave Radiation Dataset, B. Am. Meteorol. Soc., 77, 1275-1277, 1996.

Madden, R. A. and Julian, P. R.: Detection of a 40-50 Day Oscillation in the Zonal Wind in the Tropical Pacific, J. Atmos. Sci., 28, 702-708, 1971.

Matsuno, T.: Quasi-Geostrophic Motions in the Equatorial Area, J. Meteorol. Soc. Jpn., 44, 25-43, 1966.

Mote, P. W., Rosenlof, K. H., McIntyre, M. E., Carr, E. S., Gille, J. C., Holton, J. R., Kinnersley, J. S., Pumphrey, H. C., Russell, J. M., and Waters, J. W.: An atmospheric tape recorder: The imprint of tropical tropopause temperatures on stratospheric water vapor, J. Geophys. Res., 101, 3989-4006, doi:10.1029/95JD03422, 1996. 
Mote, P. W., Dunkerton, T. J., and Wu, D.: Kelvin waves in stratospheric temperature observed by the Microwave Limb Sounder, J. Geophys. Res., 107, doi:10.1029/2001JD001056, 2002.

Randel, W. J. and Wu, F.: Kelvin wave variability near the equatorial tropopause observed in GPS radio occultation measurements, J. Geophys. Res., 110, D03102, doi:10.1029/2004JD005006, 2005.

Randel, W. J. and Wu, F.: Variability of Zonal Mean Tropical Temperatures Derived from a Decade of GPS Radio Occultation Data, J. Atmos. Sci., 72, 1261-1275, doi:10.1175/JAS-D14-0216.1, 2015.

Randel, W. J., Wu, F., and Rivera Rios, W.: Thermal variability of the tropical tropopause region derived from GPS/MET observations, J. Geophys. Res., 108, 4024, doi:10.1029/2002JD002595, 2003.

Ratnam, M. V., Tsuda, T., Kozu, T., and Mori, S.: Long-term behavior of the Kelvin waves revealed by CHAMP/GPS RO measurements and their effects on the tropopause structure, Ann. Geophys., 24, 1355-1366, doi:10.5194/angeo-24-1355-2006, 2006.

Ryu, J.-H., Lee, S., and Son, S.-W.: Vertically Propagating Kelvin Waves and Tropical Tropopause Variability, J. Atmos. Sci., 65, 1817-1837, doi:10.1175/2007JAS2466.1, 2008.

Salby, M. L., Hartmann, D. L., Bailey, P. L., and Gille, J. C.: Evidence for Equatorial Kelvin Modes in Nimbus-7 LIMS, J. Atmos. Sci., 41, 220-235, 1984.

Sato, K. and Dunkerton, T. J.: Estimates of momentum flux associated with equatorial Kelvin and gravity waves, J. Geophys. Res., 102, 26247-26261, doi:10.1029/96JD02514, 1997.

Scherllin-Pirscher, B., Kirchengast, G., Steiner, A. K., Kuo, Y.H., and Foelsche, U.: Quantifying uncertainty in climatological fields from GPS radio occultation: an empirical-analytical error model, Atmos. Meas. Tech., 4, 2019-2034, doi:10.5194/amt-42019-2011, 2011a.

Scherllin-Pirscher, B., Steiner, A. K., Kirchengast, G., Kuo, Y.-H., and Foelsche, U.: Empirical analysis and modeling of errors of atmospheric profiles from GPS radio occultation, Atmos. Meas. Tech., 4, 1875-1890, doi:10.5194/amt-4-1875-2011, $2011 \mathrm{~b}$.

Scherllin-Pirscher, B., Deser, C., Ho, S.-P., Chou, C., Randel, W., and Kuo, Y.-H.: The vertical and spatial structure of ENSO in the upper troposphere and lower stratosphere from GPS radio occultation measurements, Geophys. Res. Lett., 39, L20801, doi:10.1029/2012GL053071, 2012.

Schreiner, W., Rocken, C., Sokolovskiy, S., Syndergaard, S., and Hunt, D.: Estimates of the precision of GPS radio occultations from the COSMIC/FORMOSAT-3 mission, Geophys. Res. Lett., 34, L04808, doi:10.1029/2006GL027557, 2007.

Schwärz, M., Scherllin-Pirscher, B., Kirchengast, G., Schwarz, J., Ladstädter, F., Fritzer, J., and Ramsauer, J.: Multi-Mission Validation by Satellite Radio Occultation, Final report for ESA/ESRIN No. 01/2013, WEGC, University of Graz, Austria, 2013.

Shimizu, A. and Tsuda, T.: Characteristics of Kelvin waves and gravity waves observed with radiosondes over Indonesia, J. Geophys. Res., 102, 26159-26171, doi:10.1029/96JD03146, 1997.

Solomon, S., Rosenlof, K. H., Portmann, R. W., Daniel, J. S., Davis, S. M., Sanford, T. J., and Plattner, G.-K.: Contributions of Stratospheric Water Vapor to Decadal Changes in the Rate of Global Warming, Science, 327, 1219-1223, doi:10.1126/science. $1182488,2010$.
Steiner, A. K., Lackner, B. C., Ladstädter, F., Scherllin-Pirscher, B., Foelsche, U., and Kirchengast, G.: GPS radio occultation for climate monitoring and change detection, Radio Sci., 46, RS0D24, doi:10.1029/2010RS004614, 2011.

Suzuki, J. and Shiotani, M.: Space-time variability of equatorial Kelvin waves and intraseasonal oscillations around the tropical tropopause, J. Geophys. Res., 113, D16110, doi:10.1029/2007JD009456, 2008.

Suzuki, J., Shiotani, M., and Nishi, N.: Lifetime and longitudinal variability of equatorial Kelvin waves around the tropical tropopause region, J. Geophys. Res., 115, D03103, doi:10.1029/2009JD012261, 2010.

Suzuki, J., Fujiwara, M., Nishizawa, T., Shirooka, R., Yoneyama, K., Katsumata, M., Matsui, I., and Sugimoto, N.: The occurrence of cirrus clouds associated with eastward propagating equatorial $n=0$ inertio-gravity and Kelvin waves in November 2011 during the CINDY2011/DYNAMO campaign, J. Geophys. Res., 118, 12941-12947, doi:10.1002/2013JD019960, 2013.

Tindall, J. C., Thuburn, J., and Highwood, E. J.: Equatorial waves in the lower stratosphere. I: A novel detection method, Q. J. Roy. Meteorol. Soc., 132, 177-194, doi:10.1256/qj.04.152, 2006.

Torrence, C. and Compo, G. P.: A Practical Guide to Wavelet Analysis, B. Am. Meteorol. Soc., 79, 61-78, doi:10.1175/15200477(1998)079<0061:APGTWA>2.0.CO;2, 1998.

Tsai, H.-F., Tsuda, T., Hajj, G. A., Wickert, J., and Aoyama, Y.: Equatorial Kelvin Waves Observed with GPS Occultation Measurements (CHAMP and SAC-C), J. Meteorol. Soc. Jpn., 82, 397-406, 2004.

Tsuda, T., Murayama, Y., Wiryosumarto, H., Harijono, S. W. B., and Kato, S.: Radiosonde observations of equatorial atmosphere dynamics over Indonesia: 1. Equatorial waves and diurnal tides, J. Geophys. Res., 99, 10491-1005, doi:10.1029/94JD00355, 1994.

Wallace, J. M. and Kousky, V. E.: Observational Evidence of Kelvin Waves in the Tropical Stratosphere, J. Atmos. Sci., 25, 900-907, 1968.

Wheeler, M. and Kiladis, G. N.: Convectively Coupled Equatorial Waves: Analysis of Clouds and Temperature in the Wavenumber-Frequency Domain, J. Atmos. Sci., 56, 374-399, 1999.

Wheeler, M., Kiladis, G. N., and Webster, P. J.: Large-scale dynamical fields associated with convectively-coupled equatorial waves, J. Atmos. Sci., 57, 613-640, 2000.

Wickert, J., Reigber, C., Beyerle, G., König, R., Marquardt, C., Schmidt, T., Grunwaldt, L., Galas, R., Meehan, T., Melbourne, W., and Hocke, K.: Atmosphere sounding by GPS radio occultation: First results from CHAMP, Geophys. Res. Lett., 28, 32633266, 2001.

Wickert, J., Beyerle, G., König, R., Heise, S., Grunwaldt, L., Michalak, G., Reigber, C., and Schmidt, T.: GPS radio occultation with CHAMP and GRACE: A first look at a new and promising satellite configuration for global atmospheric sounding, Ann. Geophys., 23, 653-658, 2005. 